



\section{Embryo survival and efforts to reduce ESBL cross contamination in the hatchery using One2Born hatcher baskets}

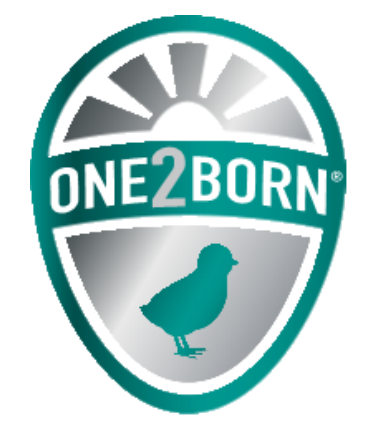

Sander Lourens and Kees Veldman 
Sander Lourens and Kees Veldman, 2018. Embryo survival and efforts to reduce ESBL cross contamination in the hatchery using One2Born hatcher baskets. Wageningen Livestock Research Report 1103.

\section{Samenvatting NL}

Een praktijkproef is uitgevoerd waarbij kuikens werden gevolgd die in de stal uitkwamen met behulp van het One2Born systeem, en werden vergeleken met kuikens die traditioneel in de broederij uitkwamen en daarna naar dezelfde stal werden getransporteerd. Er werd gekeken naar embryo overleving, naar de mogelijkheid dat kuikens tijdens transport uit de One2Born dozen kunnen ontsnappen, en naar de aanwezigheid van E-coli en ESBL bacteriën in broederij en op het vleeskuikenbedrijf. Daarnaast werden waarnemingen gedaan aan uitkomstmoment, kuikentemperatuur en kropvulling. Kuikens in het One2Born concept kwamen beter uit en hadden een $1 \%$ hogere overlevingskans, maar waren op d7 niet minder besmet met ESBL producerende E-coli bacteriën. In deze proef speelde verticale besmetting waarschijnlijk een grotere rol dan kruisbesmetting in de broederij. 95\% Van de One2Born kuikens kwamen binnen 24 uur uit. Temperatuurmetingen en kropvullingsmetingen gaven het belang aan van een tijdige bijsturing van met name de staltemperatuur.

\section{Summary UK}

An experiment was performed in practise, where chicks were monitored that hatched at the farm using the One2Born concept with respect to hatchability and the presence of E-coli and ESBL producing E-coli. These results were compared to the traditional system where chicks hatched in the hatchery and were subsequently transported to the broiler farm. Embryo survival, escape possibilities of chicks from the One2Born hatcher boxes during transport, the presence of E-coli and ESBL producing E-coli bacteria in the hatchery and at the broiler farm were investigated. Also observations were made of hatch moment, chick temperature and crop filling. Embryos in the One2Born concept had a $1 \%$ higher survival rate than hatchery chicks. ESBL contamination at $d 7$ in the broiler farm was the same for both groups. In this experiment vertical transmission of ESBL producing E-coli bacteria was more likely than cross-contamination of ESBL in the hatchery. 95\% of all One2Born chicks hatched within 24 hrs. Chick temperature measurements and crop filling rates showed the importance to consequently measure chick temperature and for action to adjust house temperature accordingly.

This report can be downloaded for free at https://doi.org/10.18174/449399 or at www.wur.nl/livestock-research (under Wageningen Livestock Research publications).

\section{(C) 2018 Wageningen Livestock Research}

P.O. Box 338, 6700 AH Wageningen, The Netherlands, T +31 (0)317 483953 , E info.livestockresearch@wur.nl, www.wur.nl/livestock-research. Wageningen Livestock Research is part of Wageningen University \& Research.

All rights reserved. No part of this publication may be reproduced and/or made public, whether by print, photocopy, microfilm or any other means, without the prior permission of the publisher or author.

Wageningen Livestock Research is NEN-EN-ISO 9001:2015 certified.

All our research commissions are in line with the Terms and Conditions of the Animal Sciences Group. These are filed with the District Court of Zwolle. 


\section{Content}

$\begin{array}{ll}\text { Summary } & 5\end{array}$

1

$\begin{array}{ll}\text { Introduction } & 7\end{array}$

2

$\begin{array}{ll}\text { Materials \& Methods } & 9\end{array}$

2.1 Hatchery and incubation $\quad 9$

2.2 Embryo survival 9

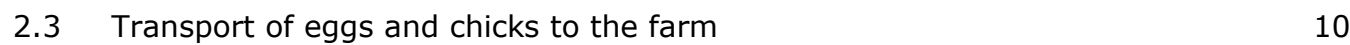

$\begin{array}{ll}2.4 \text { Housing } & 10\end{array}$

2.5 Management $\quad 12$

2.6 Chicks hatching in One2Born hatch boxes 12

2.7 Hatch time, chick temperature and crop filling 13

2.8 Detection of E. Coli and ESBL 14

2.9 Statistics $\quad 15$

$\begin{array}{llr}3 & \text { Results broiler farm experiment } & 16\end{array}$

3.1 Hatch time $\quad 16$

3.2 Chick escapement from hatch boxes 16

$\begin{array}{lll}3.3 & \text { Hatchability } & 17\end{array}$

3.4 Chick temperature $\quad 18$

$\begin{array}{lll}3.5 & \text { Crop fill } & 18\end{array}$

$\begin{array}{ll}3.6 & \text { Occurrence of E-Coli and ESBL } \\ \end{array}$

$\begin{array}{ll}\text { Literature } & 24\end{array}$ 


\section{Summary}

To study the effect of the use of One2Born hatch boxes on hatchability, chick escapement during transport, and ESBL contamination levels of chicks at the broiler farm, an experiment was conducted in practise. From a commercial hatchery, eggs were transported at ED18 of incubation to a commercial broiler farm in One2Born hatcher boxes, in order to hatch at the farm. The control group existed of chicks from the same batch of eggs, but hatched in the hatchery under standard circumstances and was transported to the same broiler farm. At the broiler farm, 12 identical units were constructed; six for One2Born eggs, and six for hatchery chicks. Additionally, in order to develop a manual to assist broiler farmers to optimise chick performance during the first week, tables to determine hatch time and to monitor hatch time, chick temperature readings and crop filling scores were developed and used to evaluate first week broiler performance. Embryos in the One2Born concept had a $1 \%$ higher survival rate than hatchery chicks. ESBL contamination at $\mathrm{d} 7$ in the broiler farm was the same for both groups. In this experiment vertical transmission of ESBL producing E-coli bacteria was more likely than cross-contamination of ESBL in the hatchery. $95 \%$ of all One2Born chicks hatched within 24 hrs. Chick temperature measurements and crop filling rates showed the importance to consequently measure chick temperature in order to adjust house temperature accordingly. 


\section{Introduction}

During recent years, the concept of farm hatching was increasingly introduced in the broiler industry in Northern and Western Europe. Eggs are incubated for 18 days, candled, packed on plastic or cardboard trays and transported to the broiler farm. Card board trays remain at the farm; plastic trays are re-used in the hatchery or breeder farm. At the broiler farm, eggs are placed on trays or boxes in the litter or on the litter. Temperature management of eggs seems to be the only and most important factor that determines hatch rates and chick quality (Lourens et al., 2005). To control egg temperature, which is the most important factor for highest hatchability and chick quality (Lourens, 20105), the broiler farmer needs to measure egg temperature and adjust house temperature on a regular basis. After hatching, chicks that hatch find water and feed when ready for it. Chick handling at the hatchery, cross contamination between batches and chick transport seem to be no issue anymore and therefore on-farm hatching is considered to be beneficial for chick health and welfare.

The idea of broilers hatching at the broiler farm was introduced by Kuijpers Kip in 1999, and first successfully tested at Het Spelderholt, Center for Applied Poultry Research in Beekbergen, The Netherlands. Later, different small scale farm hatching concepts were tested which evolved into large scale experiments. The concept of early feeding, reduced animal transport and reduced crosscontamination issues between breeder, hatchery and broiler farms was introduced in practise to improve both animal welfare and broiler performance (Lourens, 2010; Lamot et al., 2014; De Jong et al., 2016). One2Born is one of the companies that attribute to this development by the manufacturing and delivery of so-called 'Hatch Boxes", to transport hatching eggs with live embryos to the broiler farm and providing the basic environmental conditions for good hatchability.

Next to improved hatch results and reduced stress levels in day old chicks, the One2Born concept may have other positive features as well with respect to serious health issues in the broiler industry that are related to bacterial contamination of chicks. The hatchery plays an important role in the transmission and cross contamination of pathogens in the poultry production chain (Kim \& Kim, 2010; Mitchel \& Waltman, 2003). One way to solve the problem of cross-contamination in the hatchery could be on-farm hatching. In this system, eggs are transferred from the hatchery to the farm after 18 days of incubation, which is three days before hatch (Velkers et al., 2016, 2017), thereby avoiding intense exposure of chicks to possible adverse environmental conditions (temperature, dust, fluff) in hatchers, the chick processing room, and the chick holding room (before transport) as described in Nichols et al. (1967) and in De Gouw et al., 2017. In a study by Ceccarelli et al. (unpublished results) the hatchery and especially the chick processing room appeared to be a reservoir of ESBL producing E-coli bacteria. Cross contamination of ESBL-producing E-coli bacteria between flocks and batches may occur in the hatchery in the hatch area and in the chick processing room.

Extended-spectrum $\beta$-lactamase and plasmid mediated AmpC $\beta$-lactamase (ESBL/pAmpC) producing bacteria are resistant to Extended Spectrum Cephalosporins (ESC). In the Netherlands, 56.5\% of the broilers at slaughter were carriers of ESBL/pAmpC-Escherichia coli in 2016 (Veldman et al., 2017). Although prevalence in poultry varies between farms (Blaak et al., 2015), ESBL/pAmpC producing bacteria are present in all levels of the broiler production chain (Dierikx et al., 2013). The broiler production chain has a pyramidal structure, thus the presence of ESBL/pAmpC in the upper levels of the chain might influence the ESBL/ pAmpC status of lower levels in the chain, e.g. through vertical transmission as well (Nilsson et al., 2014; Zurfluh et al., 2014).

Several companies developed farm hatching devices, and One2Born exclusively offers the possibility to avoid cross contamination between breeder farm, hatchery and broiler farms because no hatcher baskets or trays are returned to neither the hatchery nor breeder farm. Instead, the hatch boxes and cardboard trays remain at the farm for biosecurity reasons. The paper materials are first used for playing materials and are consequently composed in the litter. The one main concern that stakeholders such as "Dierenbescherming" or "Wakker Dier" may have - related to animal welfare - is the occurrence of early hatching chicks during transport, that may fall out of the hatch boxes. The 
One2Born hatch boxes are claimed to be designed to avoid escapement of chicks out of the hatch boxes as long as the hatch boxes are stacked, to avoid injuries and other discomfort.

To study the effect of the use of One2Born hatch boxes on hatchability, embryo survival, chick escapement during transport, and ESBL contamination levels of chicks at the broiler farm, an experiment was conducted in practise. 


\section{Materials \& Methods}

This experiment was executed under practical circumstances in a commercial hatchery and broiler farm in the period February - March 2018. Hatching eggs were hatched at either the hatchery or at the participating broiler farm. Samples were taken in the hatchery and at the broiler farm to determine hatchability, embryo survival, and the presence of ESBL-producing E-Coli bacteria relative to the presence of all E-Coli bacteria. To support the broiler farmer to optimise hatch results and broiler performance, fill-in tables were developed to monitor chick temperature and crop filling during the first week. In the hatchery, timing is expressed as embryonic days (ED), so d18 is expressed as ED18; d21 is expressed as ED21. At the farm, day counting starts at 0 again, so d0 is when the hatchery chicks arrive at the farm and $d 7$ is when chicks in the broiler farm are 7 days old ( $7 d$ after placement of the hatchery chicks).

\subsection{Hatchery and incubation}

All eggs used in this experiment were incubated in a Petersime hatchery in one single stage incubator with a setting capacity of 57,600 eggs. Eggs originated from a 44 weeks old Ross 308 parent stock flock. At ED18, the One2Born eggs were manually candled and fertile eggs were placed on One2Born hatcher baskets (80 eggs per basket), and stacked on trolleys. One2Born hatch boxes were stacked on trolleys and placed in a running incubator to keep the eggs warm before transport to the farm. In total, 16,160 eggs were transported to the broiler farm on 202 One2Born hatcher baskets.

The remaining eggs in the incubator were candled automatically using an automated E-cat candling and transfer machine. After transfer in hatcher baskets, the eggs were placed in one Petersime 16,800 hatcher. At the day of hatching, chicks were automatically separated from the hatch debris and counted. A total of 12.851 chicks were transported to the broiler house.

\subsection{Embryo survival}

At the day of hatch (ED21), chick numbers and non-hatched eggs (dead in shell) were counted from the 6 One2Born units in the broiler houses (all non-hatched eggs per unit) and from 10 individual hatch crates in the hatchery. Each hatcher basket contained the number of chicks + dead in shell that were transferred to hatcher baskets. No additional eggs were used to replace the infertile eggs or eggs with dead embryos that were removed at d18 after candling. Aim was to determine the number of vital embryos that were alive before they were transferred to the hatcher or to the broiler farm. The break-out data of non-hatched eggs was used to determine the survival rate of embryos in both groups. Survival rate was calculated as the percentage of chicks born out of the live embryos during candling at $\mathrm{d} 18$. 


\subsection{Transport of eggs and chicks to the farm}

Transport of eggs at ED18 (Figure 1) and chicks at ED21 was arranged with a climate controlled truck. The distance to the broiler house was $170 \mathrm{~km}$, it took a 2 hrs drive to get there. The air temperature in the climate controlled truck was set at $32^{\circ} \mathrm{C}$.

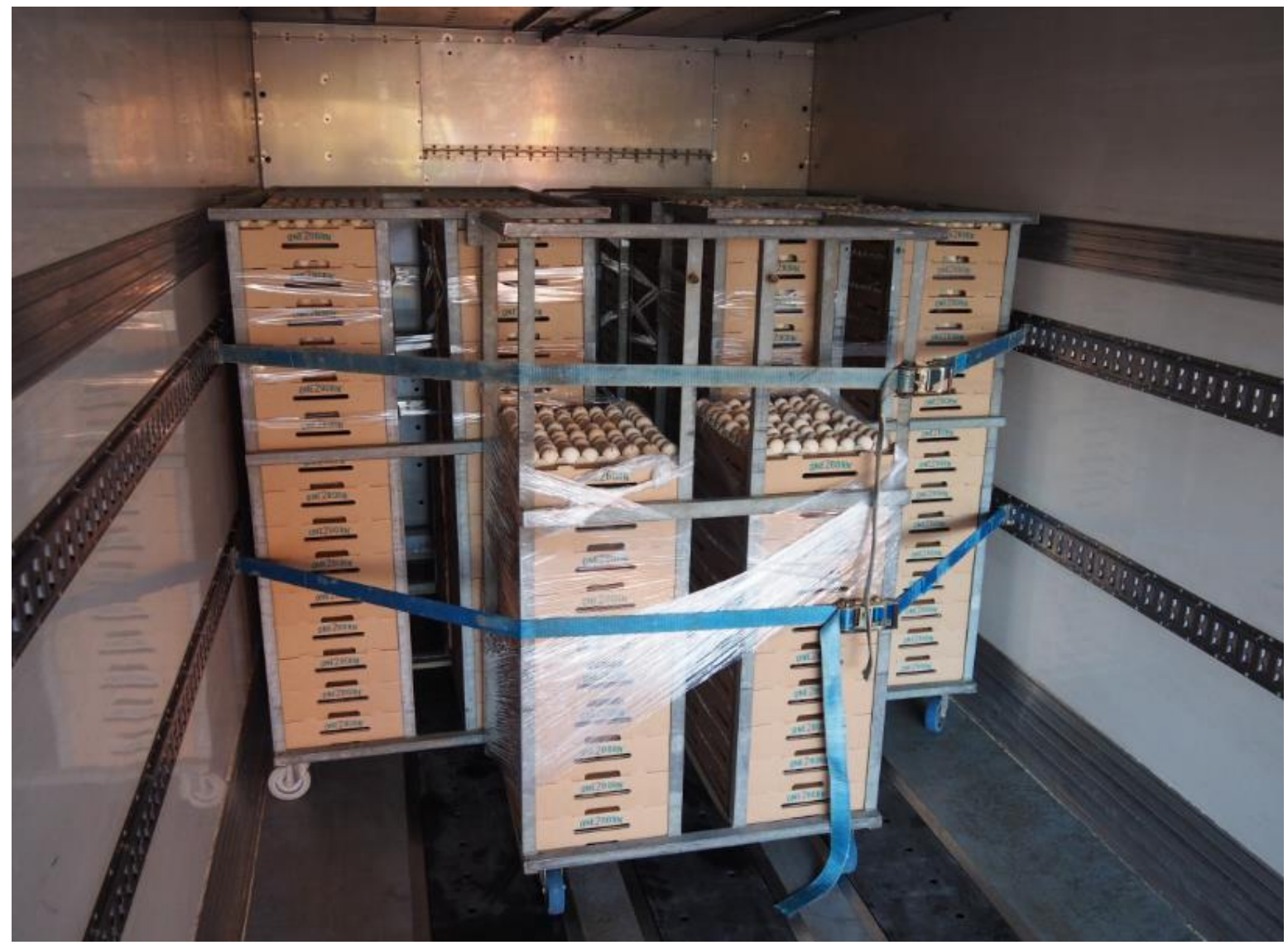

Figure 1. Transport of One2Born hatcher boxes and eggs to the broiler farm.

\section{$2.4 \quad$ Housing}

The broiler farmer prepared the farm before arrival of the eggs. The floor was covered with $1-2 \mathrm{~cm}$ of peat and the house was preheated to $35^{\circ} \mathrm{C}$. Aim was to provide the eggs the optimum eggshell temperature of $37.0-37.8^{\circ} \mathrm{C}(98-100 \mathrm{~F})$ at arrival, and subsequently following the eggshell temperature profile as advised in the One2Born manual. House temperature was adjusted, based on the required eggshell temperature.

At the broiler farm, 12 identical units of around $30 \mathrm{~m}^{2}$ were made using egg belts and cement stones (see Figures 2 and 3). Eggs were placed in one of the six units assigned to the One2Born groups. The other six units remained empty until the moment the hatchery chicks were placed at the farm. The One2Born and control units were alternated in the house (Figures 2 and 3). 


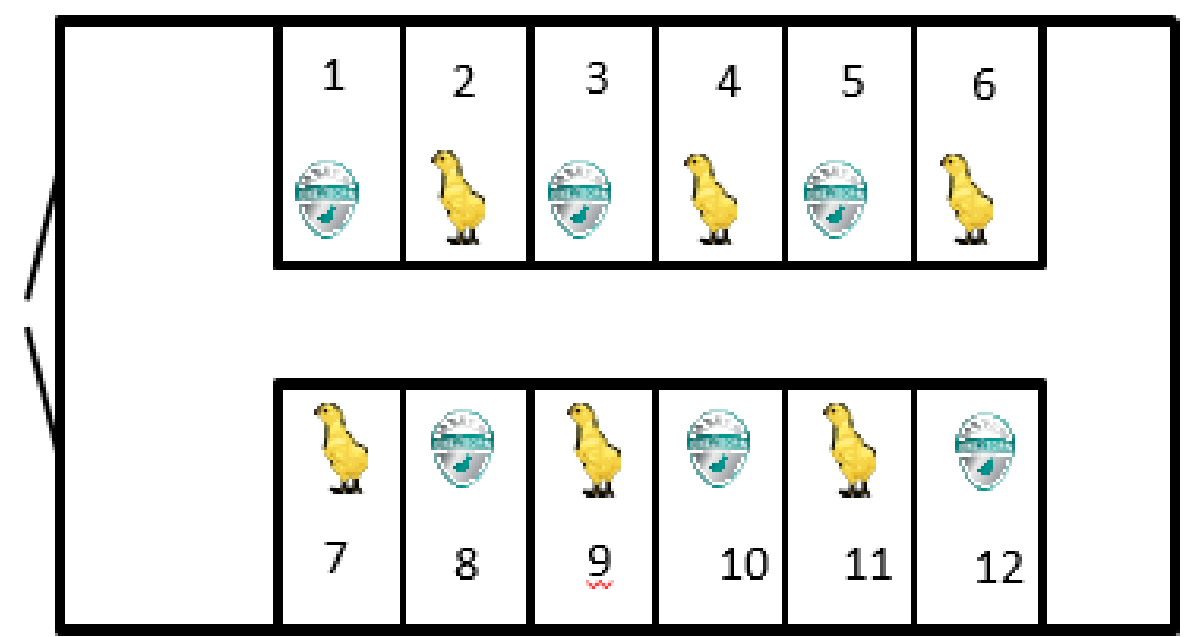

Figure 2. Overview of the broiler house with the 12 identical units for One2Born and Hatchery chicks.

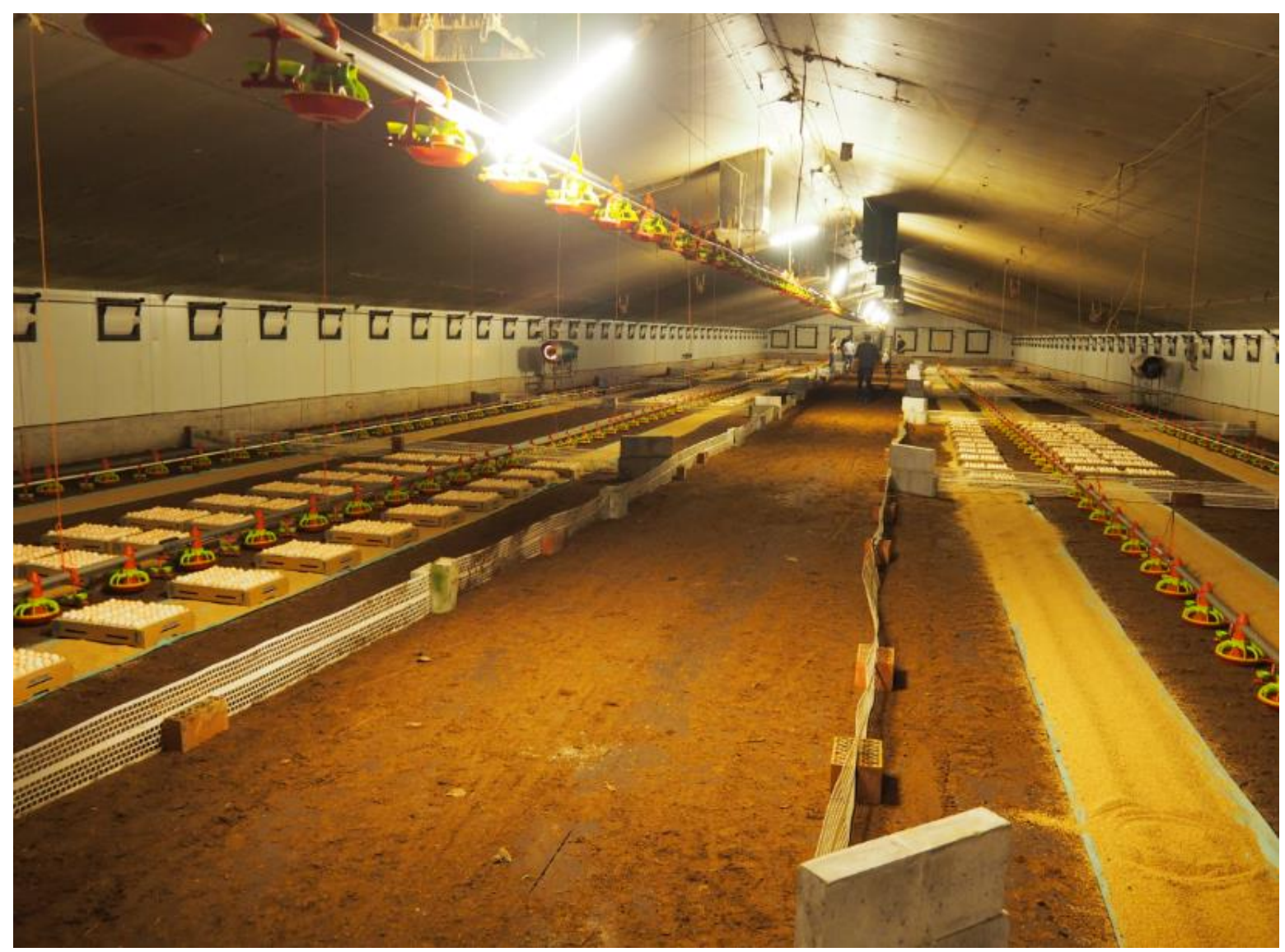

Figure 3. Overview of the experimental set-up at the broiler farm. 


\subsection{Management}

According to the One2Born manual, the house temperature was adapted daily according to the eggshell temperature readings. Eggshell temperature profile was leading; house temperature was adjusted to control the floor temperature (Table 1 ).

Table 1. House temperature setting profiles to achieve the required floor temperature and eggshell temperature levels during the hatching phase at the broiler farm.

\begin{tabular}{cccccc} 
& ED & $\begin{array}{c}\text { Eggshell } \\
\text { temperature }\left({ }^{\circ} \mathrm{C}\right)\end{array}$ & $\begin{array}{c}\text { Eggshell } \\
\text { temperature }(F)\end{array}$ & $\begin{array}{c}\text { Floor } \\
\text { temperature }\left({ }^{\circ} \mathrm{C}\right)\end{array}$ & $\begin{array}{c}\text { House } \\
\text { temperature }\left({ }^{\circ} \mathrm{C}\right)\end{array}$ \\
\hline Day -3 & 18 & $37.0-37.8$ & $98.6-100.0$ & $28-30$ & 35.5 \\
\hline Day -2 & 19 & $37.0-37.8$ & $98.6-100.0$ & 30 & 35.0 \\
\hline Day -1 & 20 & $36.5-37.2$ & $97.7-99.0$ & 30 & 34.5 \\
\hline Day 0 & 21 & n.a. & n.a. & 30 & 35.0 \\
\hline
\end{tabular}

According to the One2Born manual, $\mathrm{CO}_{2}$ level was controlled below 2,500 ppm, light intensity was at least 15 lux for 24 hrs per day (continuous light). Relative humidity was higher than $35 \%$ and wind speed across the eggs was limited to $0.15 \mathrm{~m} / \mathrm{s}$.

\subsection{Chicks hatching in One2Born hatch boxes}

Early hatching of chicks during transport may be a risk factor for animal welfare. Optimal planning will avoid early hatching and minimise the risk for chicks escaping the boxes and fall down. In unforeseen circumstances, it can be imagined that some chicks may hatch during transport to the farm. If this would happen, it would not be acceptable from an animal welfare point of view that chicks fall out of the hatch boxes. To assure that chicks remain enclosed in the One2Born hatch boxes, an experiment was executed that simulated the extreme situation that chicks remain in the One2Born hatch boxes until ED21, so until the time that the hatchery born chicks normally arrive at the farm.

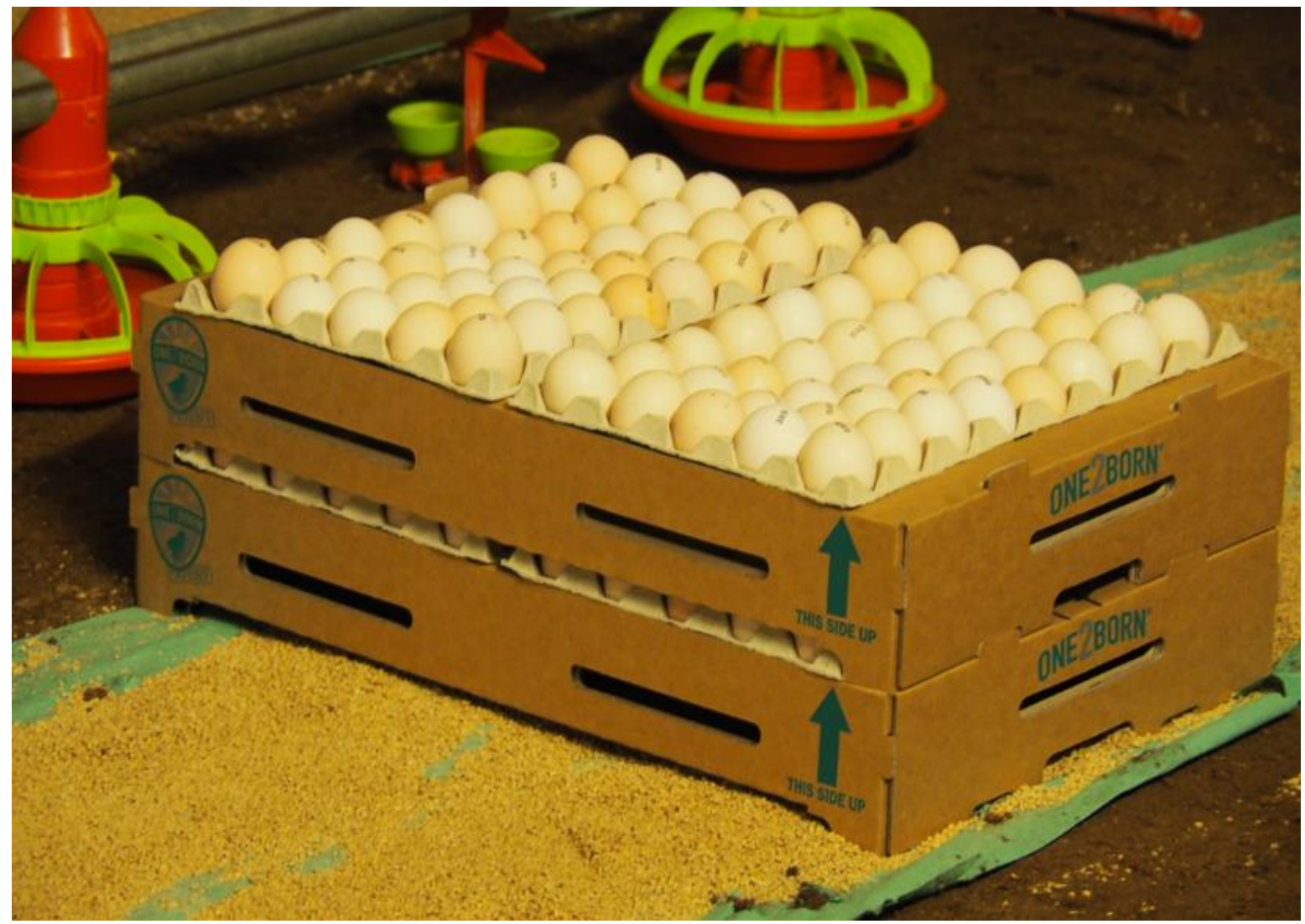

Figure 4. Two stacked One2Born boxes to prevent escapement after hatching. 
At ED18, in each of the six One2Born sections at the broiler farm, two boxes were placed on top of each other (Figure 4). The hatch boxes remained stacked until placement of hatchery chicks 3 days later at ED21. Chicks that hatched in the upper box were free to move away; chicks that hatched in the lower hatcher box were retained in their hatcher box. At ED21, the upper hatcher box was removed and non-hatched eggs and chicks were counted.

\subsection{Hatch time, chick temperature and crop filling}

The broiler farmer used a fill-in form on a daily basis to count the number of eggs that hatched (out of 160 eggs, see figure 5) and to measure rectal chick temperatures and crop filling every four hours.

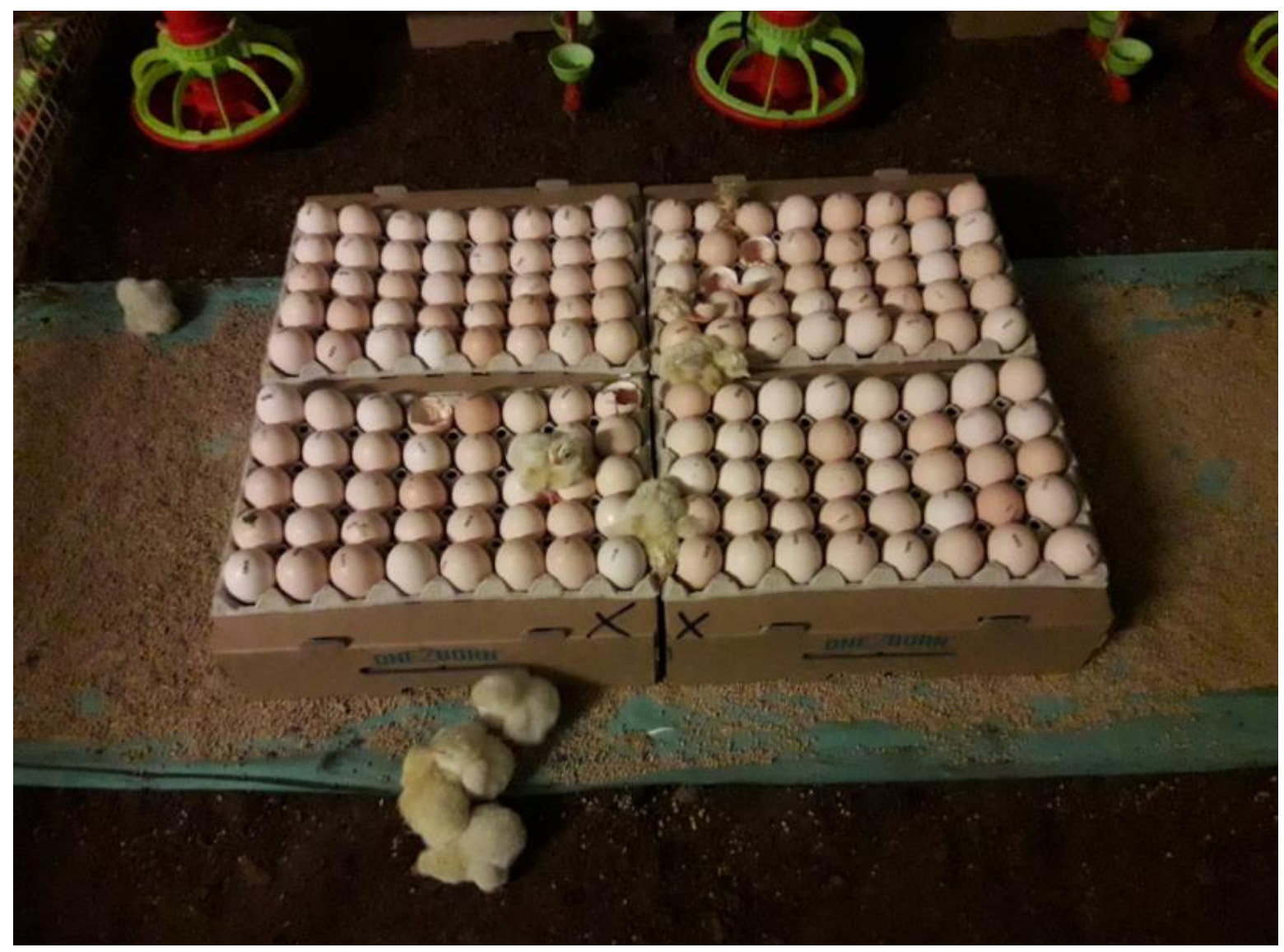

Figure 5. Two One2Born hatcher boxes with 160 eggs to determine hatch time and hatch window.

The One2Born manual recommends $40.5^{\circ} \mathrm{C}$ for chick temperatures during the first week. Recordings of rectal temperature were done on dried-up chicks; so newly hatched chicks were given time to dry up. Temperatures were taken every 4 hrs from the moment of hatching onwards in 10 checks per unit. In the same chicks, crop filling was determined by palpation of the crop, to feel any signs of ingested feed. Crops can feel empty (score 0), slight signs of feed (score 1) or can be filled with feed (score 2). Part of the data form is shown in Figure 6. 


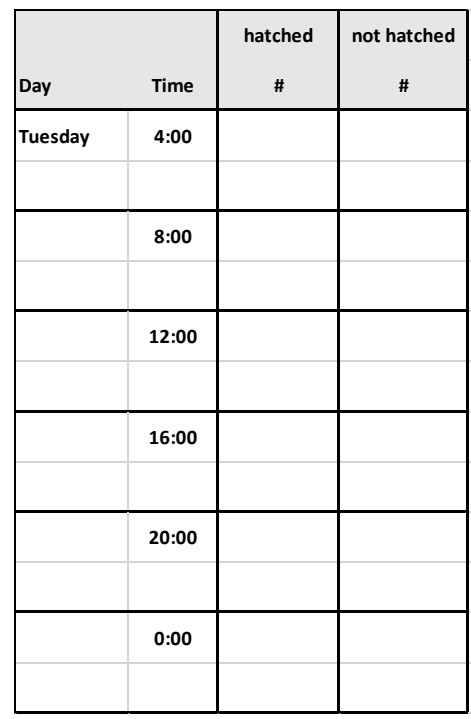

\begin{tabular}{|c|c|c|c|c|c|c|c|c|c|c|}
\hline & \multicolumn{10}{|c|}{ chicken } \\
\hline & 1 & 2 & 3 & 4 & 5 & 6 & 7 & 8 & 9 & 10 \\
\hline Temperature (ㄷ) & & & & & & & & & & \\
\hline Crop filling (0-1-2) & & & & & & & & & & \\
\hline Temperature (ㄷ) & & & & & & & & & & \\
\hline Crop filling (0-1-2) & & & & & & & & & & \\
\hline Temperature (ㄷ) & & & & & & & & & & \\
\hline Crop filling (0-1-2) & & & & & & & & & & \\
\hline Temperature (ㄷ) & & & & & & & & & & \\
\hline Crop filling (0-1-2) & & & & & & & & & & \\
\hline Temperature (ㄷ) & & & & & & & & & & \\
\hline Crop filling (0-1-2) & & & & & & & & & & \\
\hline Temperature (ㄷ) & & & & & & & & & & \\
\hline Crop filling $(0-1-2)$ & & & & & & & & & & \\
\hline
\end{tabular}

Figure 6. Fill-in form to monitor hatch time, chick temperature and crop-filling.

\subsection{Detection of E. Coli and ESBL}

In the hatchery, samples were taken from incubator walls, floor, ventilator and ventilation ducts and at various places in the hatchery, using sponges.

In the setter (after ED18 of incubation), the hatcher (clean before transfer) and the warm egg storage (before egg transport to the farm), samples were taken from the walls $(n=5)$, floor $(n=5)$ and ventilation (propeller and ducts; $n=5$ ). From two manual egg transfer devices, 5 suction cups were sampled ( $n=5$ per device). The walls $(n=5)$ and floor $(n=5)$ from the truck were sampled. Clean hatcher baskets were sampled $(n=5)$ as well as 5 individual eggs before transfer to the hatcher baskets. The suction cups of the manual E-cat transfer machine were also sampled $(n=5)$.

From the dirty hatcher at ED21, the walls $(n=5)$ were sampled and fluff was taken as sampling material. In the chick processing room, three different belts were sampled ( $n=5$ per belt). Samples were taken from the chick storage room $(n=5)$ and the clean chick transport boxes $(n=5)$. The clean truck for chick transport was sampled at the walls $(n=5)$ and at the floor $(n=5)$.

At the farm at ED18, samples were taken from the feeding pans $(n=5)$, drinking lines $(n=5)$ and from the walls $(n=5)$. Also some litter material was taken for analysis. At ED21, before placement of the chicks, samples were taken in each unit from feed ( $n=12$ units), water $(n=2$ lines) and litter $(n=12$ units). At d7, samples were taken in the 12 units from the individual chicks ( $n=10$ cloaca swab samples) and from the litter $(n=12)$. The samples from the individual chicks per unit were pooled for further analysis.

After sampling, sponges were selectively cultured ( $3 \mathrm{~mL}$ LB broth versus $400 \mathrm{~mL}$ LB, supplemented with $1 \mathrm{mg} / \mathrm{L}$ cefotaxime). After overnight incubation at $37^{\circ} \mathrm{C}, 10 \mu \mathrm{L}$ broth was inoculated on MacConkey plates supplemented with $1 \mathrm{mg} / \mathrm{L}$ cefotaxime and incubated overnight at $37^{\circ} \mathrm{C}$.

At d7, ten chicks per pen were individually sampled with a swab in the cloaca. Swabs used were weighed before and after sampling to determine the amount of faeces collected. Swabs were suspended in $1 \mathrm{~mL}$ saline solution and tenfold dilution series were made to quantify the colonyforming units (cfu) of ESBL/pAmpC-E. coli and total E. coli per $\mathrm{mL}$, using MacConkey plates with and without $1 \mathrm{mg} / \mathrm{L}$ cefotaxime. Based on the amount of faeces on the swabs cfu/gram faeces was calculated. 
Per sample one typical E. coli colony from the MacConkey $+1 \mathrm{mg} / \mathrm{L}$ was confirmed with MALDI-TOF (MALDI Biotyper, Bruker) and resistance to third generations cefalosporines was confirmed with broth microdilution test according to ISO standards (20776-1:2006) using Sensititre plates.

\section{$2.9 \quad$ Statistics}

For all data, averages and SEM were calculated. For normally distributed data the independent t-test was used (IBM SPSS) to determine if results in the One2Born group differed significantly from the Hatchery group. For the E-coli and ESBL analysis, first an independent t-test (assumes normally distributed data) was run for the log transformed data, and in the case of significant differences $(P<0.05)$ the less specific non-parametrical Wilcoxon statistical test (when data are not normally distributed) was used to analyse the log data. 


\section{Results broiler farm experiment}

\subsection{Hatch time}

In each section where One2Born boxes were placed, the number of hatched chicks were counted every 4 hrs. This yielded a hatch curve as can be seen in Figure 7.

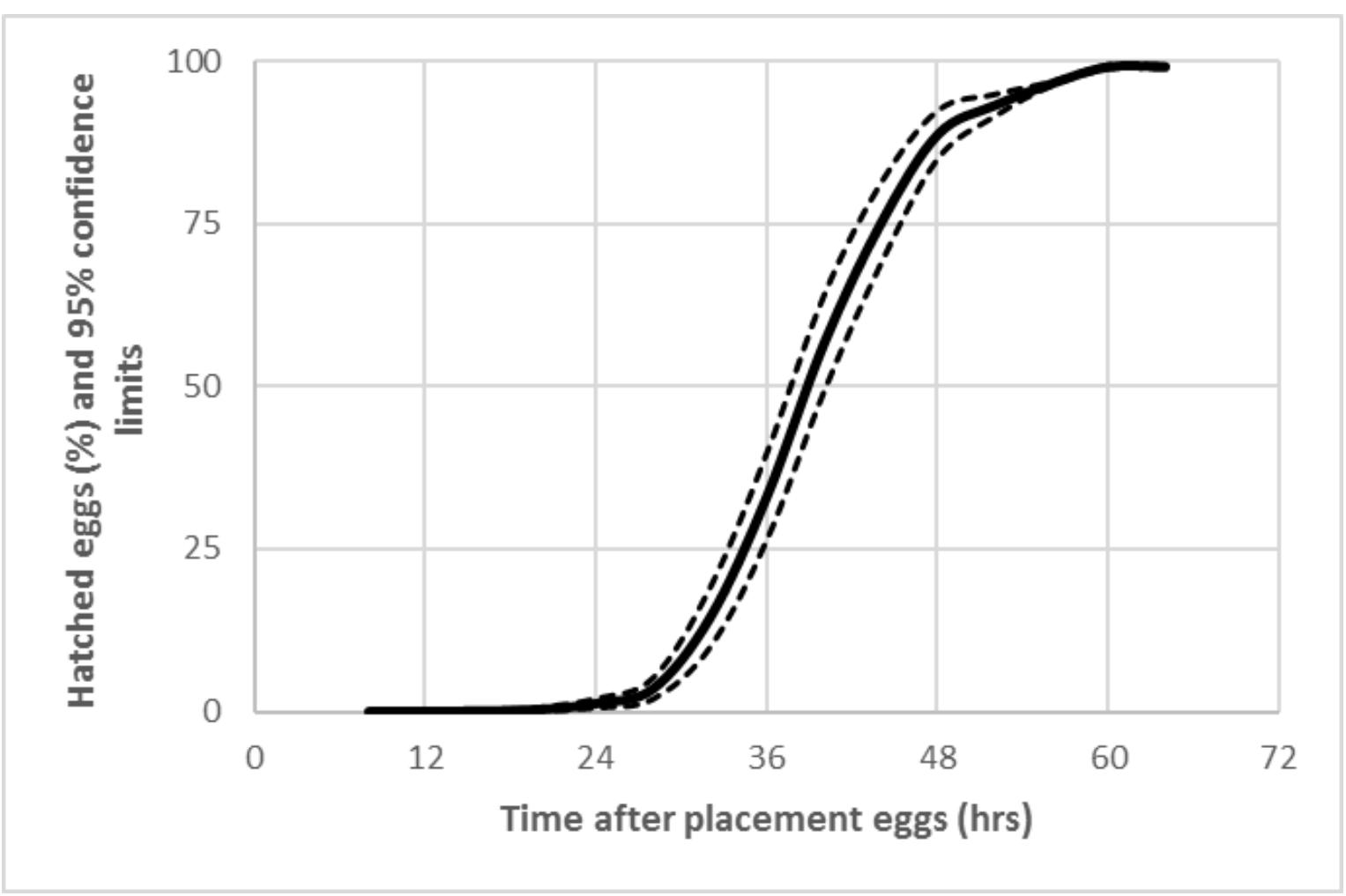

Figure 7. Hatch curve with $95 \%$ confidence zone for One2Born chicks at the broiler farm.

The solid line (Figure 7) represents the average hatch curve, the dotted lines represent the $95 \%$ confidence interval showing the range where $95 \%$ of the data points range. First chicks hatched after $24 \mathrm{hrs}$ of placement in the house. On average, $50 \%$ of the eggs hatched out after 42 hrs after placement of eggs at the farm. The so called hatch window was around 36 hrs (between 24 and 60 hrs after egg placement).

\subsection{Chick escapement from hatch boxes}

One One2Born hatcher box with a total of 80 eggs was closed off by another One2Born hatcher box placed on top of the first, to avoid escape of chicks from the box. It was counted how many eggs hatched, and how many chicks escaped. Results are presented in Table 2.

Table 2. Chick escapement from One2Born hatch boxes between ED18-21.

\begin{tabular}{|c|c|c|c|c|}
\hline & Eggs placed (\#) & $\begin{array}{c}\text { Eggs not hatched } \\
(\#)\end{array}$ & Chicks counted (\#) & Chicks escaped (\#) \\
\hline Box 1 & 80 & 1 & 79 & 0 \\
\hline Box 2 & 80 & 3 & 77 & 0 \\
\hline Box 3 & 80 & 0 & 80 & 0 \\
\hline Box 4 & 80 & 2 & 78 & 0 \\
\hline Box 5 & 80 & 0 & 80 & 0 \\
\hline Box 6 & 80 & 1 & 79 & 0 \\
\hline
\end{tabular}


No chicks were able to escape from the hatch boxes in the period between ED18-21. All chicks that hatched retained in the One2Born hatch box and appeared alive, vivid and were able to walk away freely once released from their hatcher box.

\subsection{Hatchability}

In the One2Born concept the survival of embryos (99.0\%) was higher than in the hatchery (97.4\%), see Table 3. On the other hand, $0.6 \%$ of the chicks were selected as second grade in the hatchery and removed from the first grade chicks that were transported to the broiler farm. The difference in hatchability was significantly $1.0 \%$ higher in the One2Born concept. In general, the hatch of transferred eggs in both systems is lower than embryo survival rate, because also cracked eggs, infertile eggs and eggs with dead embryos were transferred to the hatcher or to the farm. There was no significant difference in candling efficiency between the manually candled eggs and the E-cat machine candled eggs with respect to removal of cracked eggs, infertile eggs or eggs with early dead embryos (embryos died before ED18).

Table 3. Hatchability and embryo survival in the One2Born and hatchery system with standard errors of the mean (SEM) and significance levels.

\begin{tabular}{lcccc} 
Hatch of transferred eggs & One2Born & Hatchery & SEM & P-value \\
\hline Hatch of transferred live embryos at d18 & 96.7 & 95.9 & 0.38 & $\mathrm{P}<0.05$ \\
\hline 2nd grade + dead chicks & 99.0 & 97.4 & 0.26 & $\mathrm{P}<0.05$ \\
\hline Cracked eggs & - & 0.6 & 0.09 & - \\
\hline Infertile eggs transferred & 0.5 & 0.3 & 0.14 & No \\
\hline Dead embryos transferred $(<18 \mathrm{~d})$ & 0.1 & 0.2 & 0.07 & No \\
\hline
\end{tabular}




\subsection{Chick temperature}

The first two days after the start of hatching, temperatures of chicks were taken every 4 hrs after hatching in 10 chicks per section that dried up and were able to walk and explore the farm. After 2 days, temperatures were taken twice per day until d7. It can be seen in Figure 8 that the average rectal temperature in newly hatched chicks was around $38.0^{\circ} \mathrm{C}$, and that rectal temperatures increased slowly. Remarkably, the hatchery chicks had higher rectal temperatures than the One2Born chicks. In both groups however, chick temperatures remained below the advised temperature of $40.5^{\circ} \mathrm{C}$ during the first week of age.

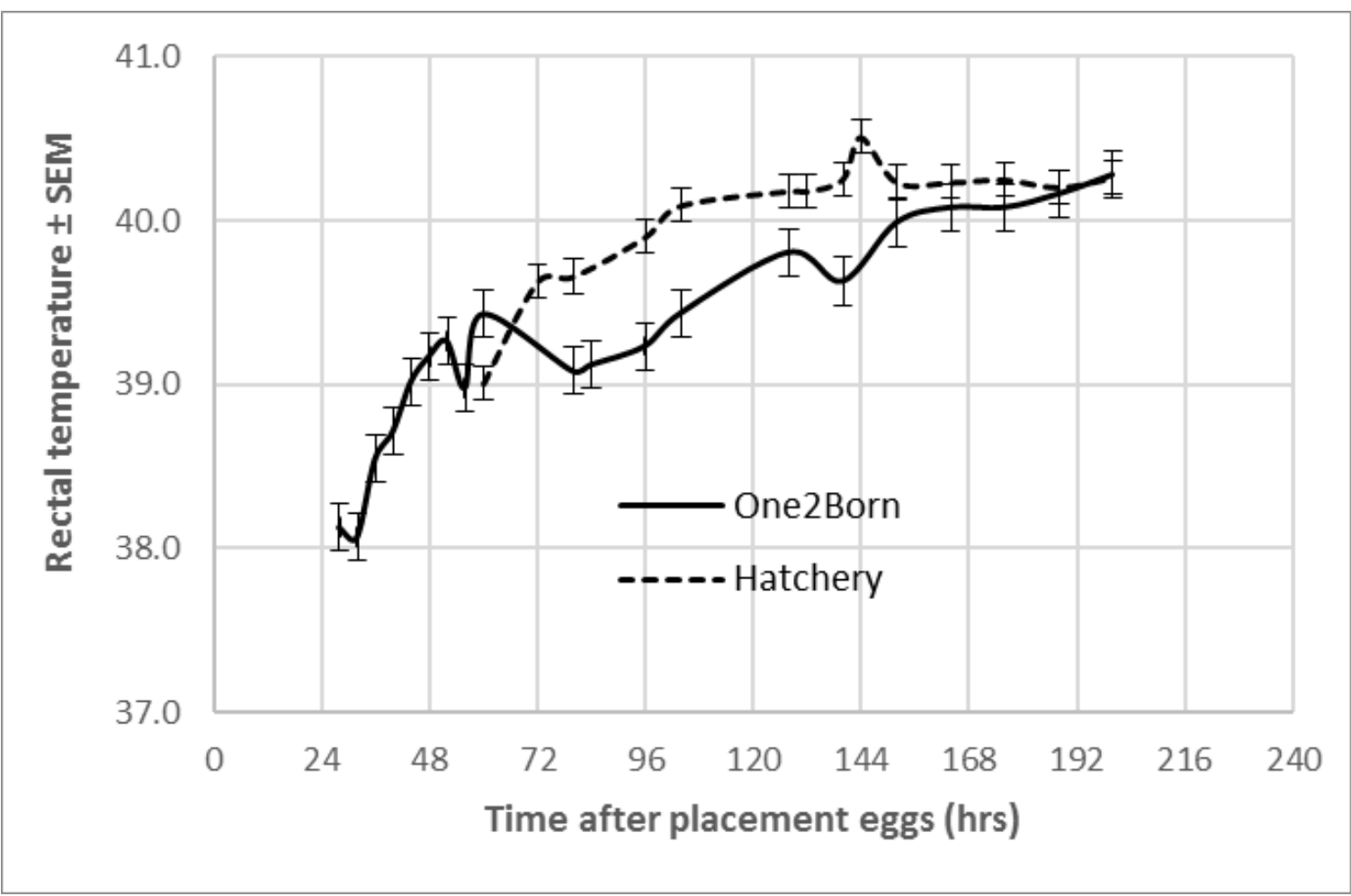

Figure 8. Rectal chick temperatures and SEM for One2Born chicks and Hatchery chicks during the first week at the broiler farm.

\subsection{Crop fill}

Crop fill was determined every 4 hrs after hatching in 10 chicks per section that dried up and were able to walk and explore the farm. Crops were palpated to feel the presence of food items. Results are summarised in Figure 9. It can be seen from Figure 9 that food items could be felt present after 72 hrs, which is around the time where hatchery chicks were picking up food items as well. After that moment, almost 2 days after the start of hatching, One2Born chicks appeared to start feeding more quickly. However, 100\% crop filling was observed in both One2Born and hatchery chicks after 144 hrs after egg placement, which is 3 days after the emergence of the first chicks. 


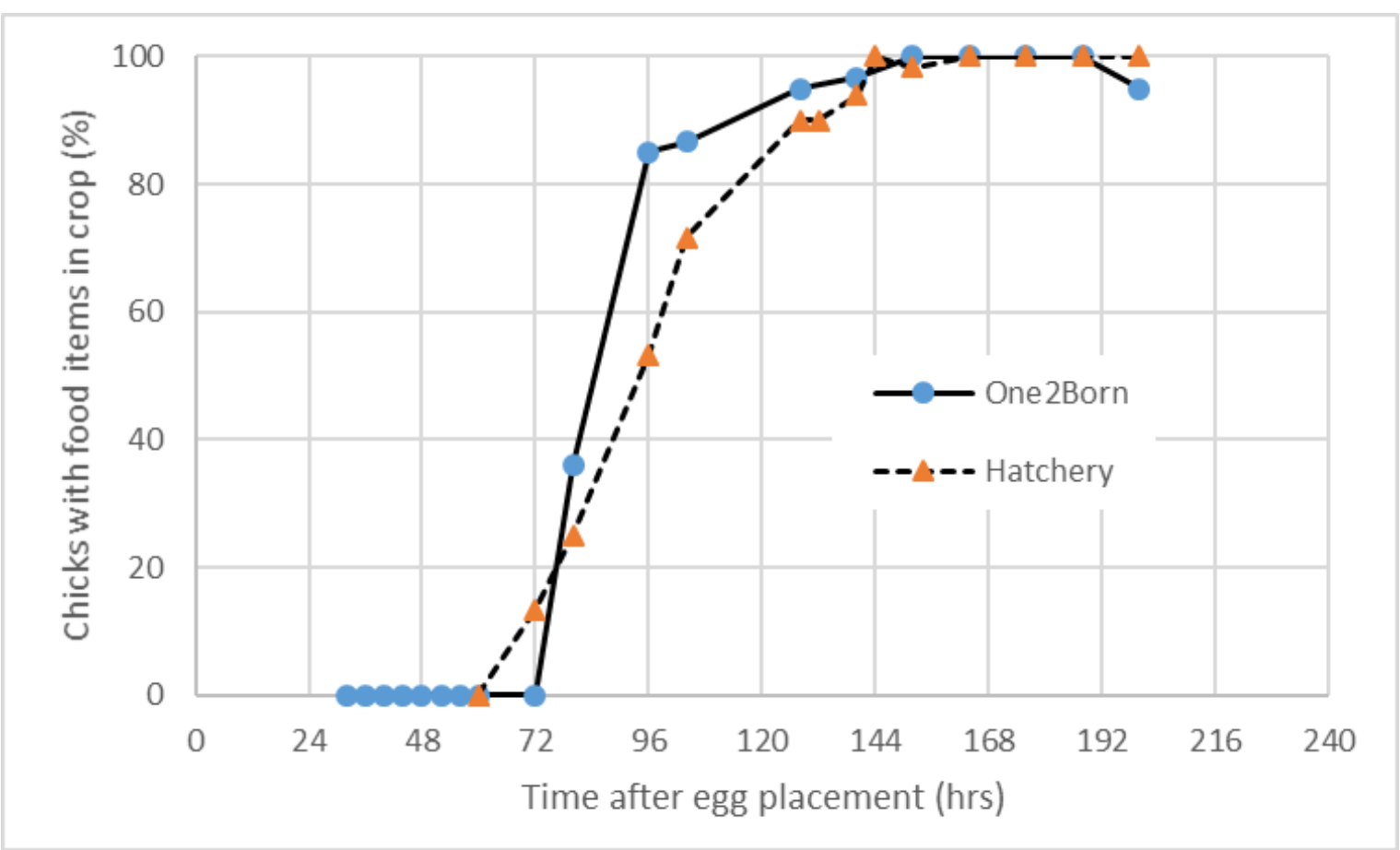

Figure 9. Crop filling development in One2Born chicks and Hatchery chicks in the first week of life.

\subsection{Occurrence of E-Coli and ESBL}

In the hatchery, samples were taken using sponges to determine presence of E-coli bacteria and ESBL producing E-coli bacteria at $\mathrm{d} 18$ (candling and transfer of eggs to One2Born hatch boxes or traditional hatch boxes. An overview of these results is given in Table 4.

Table 4. E-coli and ESBL presence (pos or neg) in the hatchery at ED18.

\begin{tabular}{lllll}
\hline SD18 hatchery & walls & \# samples & E-Coli & ESBL \\
\hline & floor & 5 & neg & neg \\
\hline Warm egg storage & ventilation & 5 & neg & neg \\
\hline & walls & 5 & neg & neg \\
\hline floor & ventilation & 5 & neg & neg \\
\hline Truck & sides, floor & 5 & pos & neg \\
\hline Egg transfer cups 1 & & 5 & pos & neg \\
\hline Egg transfer cups 2 & & 5 & pos & neg \\
\hline Hatcher & walls & 5 & pos & neg \\
\hline & floor & 5 & pos & neg \\
\hline One2Born Hatcher baskets & ventilation & 5 & pos & neg \\
\hline Clean hatcher baskets & & 5 & pos & neg \\
\hline Eggs & before transfer & 5 & pos & neg \\
\hline Egg transfer machine & & 5 & neg & neg \\
\hline
\end{tabular}

It can be seen from Table 4 that the setters, the clean hatcher baskets and the manual egg transfer devise were free of E-coli bacteria. Positive E-coli samples were found on the floor and ventilation system of the warm egg storage, the truck, the egg transfer suction cups, and the hatcher (yet without eggs). No ESBL producing E-coli were observed. The One2Born hatcher baskets were free from E-coli and ESBL producing E-coli. 
At ED21, at the day of the planned hatch of chicks in the hatchery, the hatcher, chick processing belts, chick store and chick boxes were positive for E-coli. The clean truck for transport of chicks was free from E-coli. No ESBL producing E-coli were observed at all (Table 5).

Table 5. E-coli and ESBL presence (pos or neg) in the hatchery at ED21.

\begin{tabular}{lllll}
\hline Hatcher & walls & \# samples & E-Coli & ESBL \\
\hline Hatcher & fluff & 5 & pos & neg \\
\hline chicken belt 1 & & 5 & pos & neg \\
\hline chicken belt 2 & & 5 & pos & neg \\
\hline chicken belt 3 & 5 & pos & neg \\
\hline chick store & 5 & pos & neg \\
\hline chick boxes & 5 & pos & neg \\
\hline truck & 5 & pos & neg \\
\hline
\end{tabular}

At ED18 at the broiler farm, also samples were taken to determine the presence of E-coli and ESBL producing E-coli bacteria. Feeding pans, the drinking water in the drinking lines, the litter material and the walls were all free of E-coli and ESBL (Table 7).

Table 6. E-coli and ESBL presence (pos or neg) in the broiler house at ED18 / d-3.

\begin{tabular}{lccc} 
ED18 Farm & \# samples & E-Coli & ESBL \\
feeding pans & 5 & neg & neg \\
\hline drinking water & 5 & neg & neg \\
\hline litter & 5 & neg & neg \\
\hline walls & 5 & neg & neg \\
\hline
\end{tabular}

At ED21 samples were taken at the broiler farm again; results are in Table 7. At ED21, and before placement of the hatchery chicks, the litter and feed was sampled in the 12 units. The litter was now positive for E-coli in all units ( 6 units positive for as well One2Born and Hatchery chicks). Feed was positive for E-coli as well in 4 units. Also the water in the water lines were positive for E-coli. However, no ESBL producing E-coli were yet detected.

Table 7. E-coli and ESBL presence (pos or neg) in the broiler farm at ED21 / d0. For litter and feed one sample was taken in each unit (6 units per group).

\begin{tabular}{lllll} 
ED21 Farm & \multicolumn{2}{c}{ ESBL } \\
\hline Litter & One2Born & Hatchery & One2Born & Hatchery \\
\hline Feed & Pos $(6 / 6)$ & Pos $(6 / 6)$ & Neg $(0 / 6)$ & Neg $(0 / 6)$ \\
\hline
\end{tabular}

At d7, samples for E-coli and ESBL were taken in the broiler farm in the 12 different sections of One2Born and Hatchery chicks. All samples were positive for both E-coli bacteria and positive for ESBL producing bacteria. Also quantitative counts were made. These results are shown Table 8 and in the figures 10-13 below. No significant differences could be observed between One2Born chicks and Hatchery chicks for E-coli and for ESBL producing E-coli.

Table 8. Quantitative counts of E-coli and ESBL (log cfu/g) in litter and chicks (cloaca samples) in One2Born and Hatchery units at $d 7$.

\begin{tabular}{lcccccc} 
& One2Born & Hatchery & Significant effect $(P<0.05)$ & $\begin{array}{c}\text { One2Born } \\
\text { Hatchery }\end{array}$ & $\begin{array}{c}\text { Significant } \\
\text { effect } \\
(P<0.05)\end{array}$ \\
\hline Litter & 5.0 & 4.2 & no & 3.3 & 3.4 & no \\
\hline Chicks & 7.2 & 6.2 & no & 4.2 & 4.8 & no \\
\hline
\end{tabular}




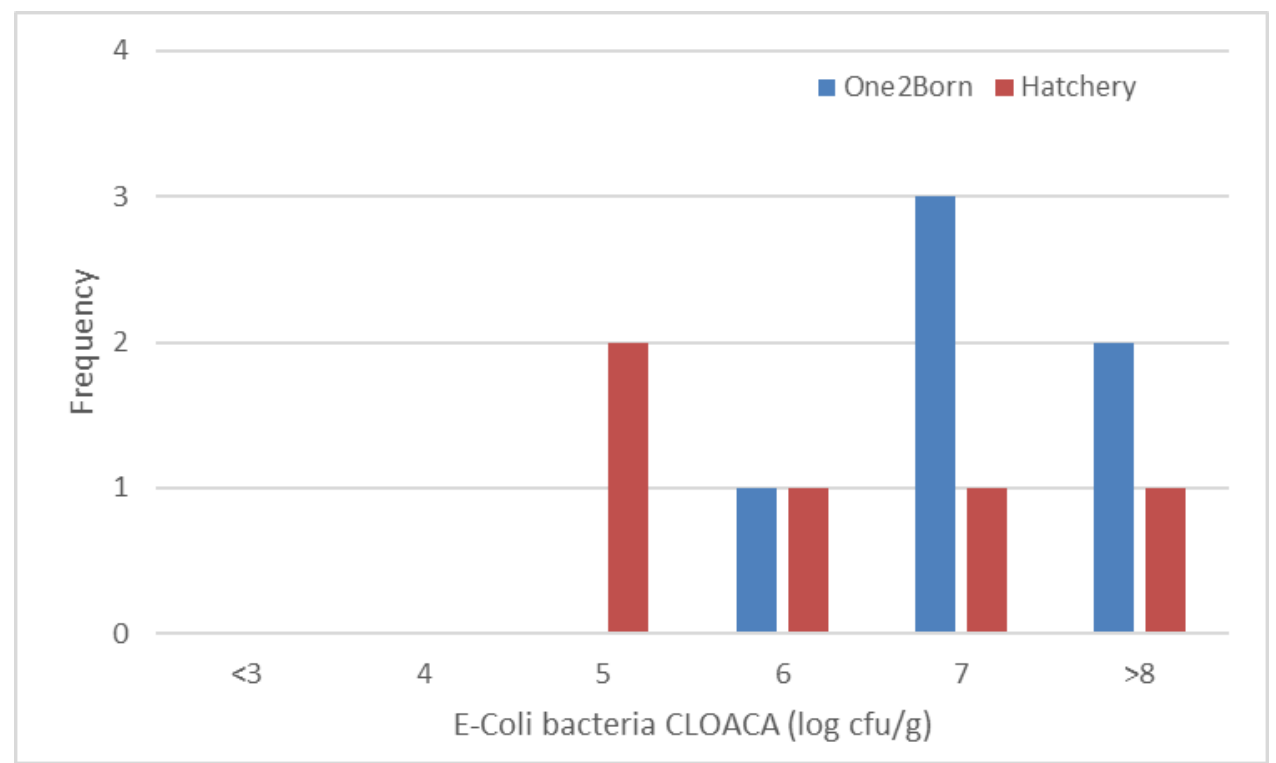

Figure 10. E-coli bacteria (log cfu/g) in the cloaca samples in One2Born and Hatchery chicks $(n=6)$.

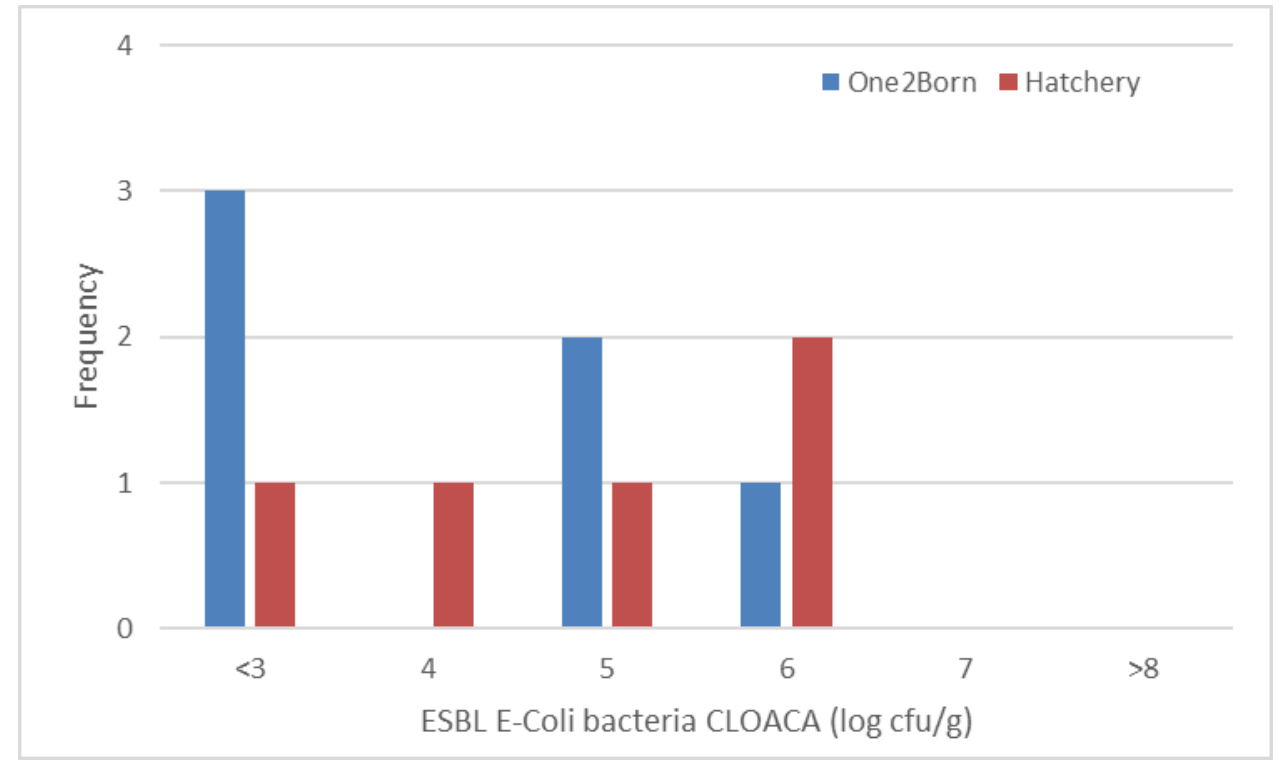

Figure 11. ESBL producing E-coli bacteria (log $\mathrm{cfu} / \mathrm{g}$ ) in the cloaca samples in One2Born and Hatchery chicks $(n=6)$. 


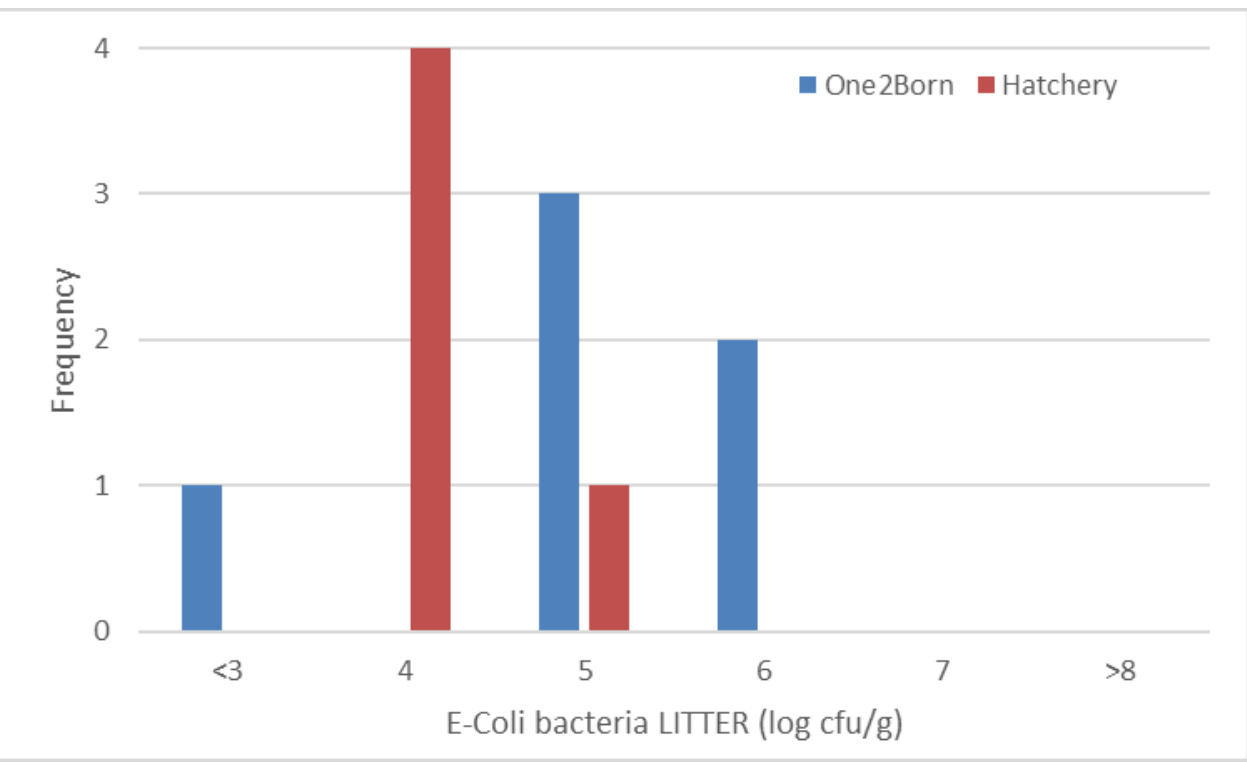

Figure 12. E-coli bacteria (log cfu/g) in the litter samples in One2Born and Hatchery chicks $(n=6)$.

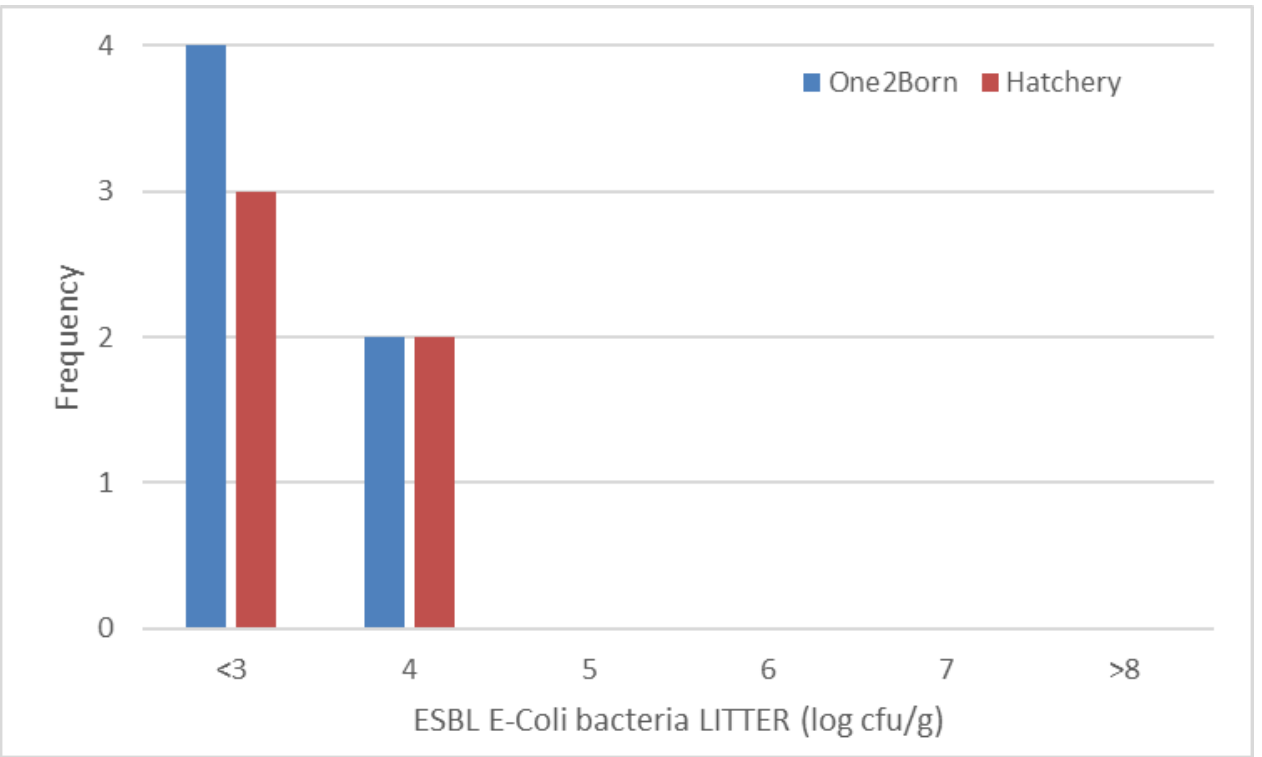

Figure 13. ESBL producing E-coli bacteria (log cfu/g) in the litter samples in One2Born and Hatchery chicks $(n=6)$. 


\section{Discussion and conclusion}

The One2Born chicks hatched at a very high rate, and only $1 \%$ of the alive embryos at ED18 died between ED18-21. In the hatchery, embryonic mortality rate in the same period was twice as high ( $2 \%$ ). On top of this $1.0 \%$ higher hatch rate, the hatchery staff selected $0.6 \%$ of the chicks with visual defects as bad navels or malformations. In the One2Born system the second grade chicks were likely selected in a later stage or maybe died in the first week.

All chicks that hatched in the One2Born hatch boxes remained in the hatch box until ED21. From this it can be concluded that no single chick was able to escape from the hatch box during transport to the farm, as long as hatcher boxes remain stacked. It is advised to place an empty One2Born box on top of the stack to avoid escapement of early hatching chicks in the highest hatcher box.

The hatch curve showed a hatch window of 36 hours, and $95 \%$ of the chicks hatched within 24 hours. The hatchery chicks arrived when the latest One2Born chicks emerged from the shells. One2Born chicks hatched later, and had a lower body temperature compared to hatchery chicks. This lower body temperature in One2Born chicks lasted until 4 days of age. The body temperatures of both One2Born and the hatchery chicks was below the advised body temperature of $40.5^{\circ} \mathrm{C}$ (Lourens and Kuijpers, 2002) for 3 to 4 days. Crop filling in One2Born chicks that had access to feed and water after hatching was observed only after 2 days of the start of hatching, which is around the time of arrival of the hatchery chicks. Despite detection of feed particles in the crop by palpation, chicks still may have consumed some small feed particles. Delayed feeding time is likely the result of the too low body temperatures of the One2Born chicks in that period. Chicks that are cold stressed do not start to feed in an early stage (Lourens and Veldkamp, 2014). The hatchery chicks were also cold stressed. Different from this study, in other studies about farm hatching it appeared difficult to avoid overheating of eggs and chicks (Harn, van et.al., 2012).

The hatchery was negative for ESBL producing E-coli bacteria at all places we sampled, so cross contamination of ESBL producing E-coli bacteria was not likely. This situation was different than the situation described by Ceccarelli (unpublished results), where both the hatchery and the broiler farm environment was positive for ESBL producing E-coli bacteria. In the current experiment, also at the broiler farm, no ESBL producing E-coli bacteria could be detected before arrival of the hatchery chicks. Vertical transmission of ESBL producing E-coli bacteria appears to play a more important role, since at d7 all samples from the litter and chicks were positive for ESBL producing E-coli bacteria. This is more in accordance to the results described by Dierixk et al. (2013) and Dame-Korenvaar et al. (2017). No differences in qualitative and quantitative ESBL contamination could be observed between One2Born chicks and hatchery chicks.

It can be concluded from this experiment, that

- embryo survival in eggs on One2Born hatcher trays is $1 \%$ higher compared to the standard procedure where chicks hatch in the hatchery.

- $\quad$ As long as the One2Born hatcher trays are stacked, chicks will not escape from the hatcher boxes and remain inside the hatcher boxes.

- Using One2Born hatcher baskets for transport of hatching eggs between hatchery and broiler farm, early hatching chicks will run no risk for physical injuries or impaired welfare.

- $\quad$ The hatchery tested negative for ESBL producing E-coli bacteria so cross contamination was no issue.

- The One2Born hatcher trays were negative for E-coli and ESBL producing E-coli, assuring no contributing risks to transmission of these bacteria from the hatchery to the broiler farm.

- ESBL contamination of broilers is more the result of vertical contamination between breeder farm and broiler farm than of cross contamination in the hatchery.

- Measurement of chick temperature is necessary to optimise environmental conditions. 


\section{Literature}

Blaak, H., van, H.A., Hamidjaja, R.A., van der, P.R., Kerkhof-de, H.L., de Roda, H.A., and Schets, F.M. (2015). Distribution, numbers, and diversity of ESBL-producing E. coli in the poultry farm environment. PLoS One 10, e0135402.

Dierikx, C.M., Van, D.G., Smith, H.E., Kant, A., and Mevius, D.J. (2013). Presence of ESBL/AmpC -producing Escherichia coli in the broiler production pyramid: a descriptive study. PLoS One 8.

Dame-Korevaar, A., E.A.J. Fischer, A. Stegeman, D. Mevius, A. van Essen-Zandbergen, F. Velkers, and J. van der Goot. (2017). Dynamics of CMY-2 producing E. coli in a broiler parent flock. Veterinary Microbiology 203; pp211-214.

De Gouw, P., L.J.F. Van de Ven, A. Lourens, B. Kemp and H. van den Brand. 2017. Effects of dust, formaldehyde and delayed feeding on early postnatal development of broiler chickens. Research in Veterinary Science 112 (2017) 201-207.

De Jong, I.C., Van Riel, J., Lourens, A., Bracke, M.B.M., and Van den Brand, H. (2016). Effects of food and water deprivation in newly hatched chickens. A systematic literature review and metaanalysis. Wageningen Livestock Research, Report 999.

Harn, J. van, A. Lourens and Gunnink, H. (2012). Uitkomen van vleeskuikens in de stal. Wageningen UR Livestock Report.

Kim, J.H., and Kim, K.S. (2010). Hatchery hygiene evaluation by microbiological examination of hatchery samples. Poultry Science, 89, 1389-1398.

Lamot, D. M., Van de Linde, I. B., Molenaar, R., Van der Pol, C. W., Wijtten, P. J. A., Kemp, B., and Van den Brand, H. (2014). Effects of moment of hatch and feed access on chicken development. Poultry Sscience, 93, 2604-2614.

Lourens, A., and Kuijpers M. (2002). Control temperature of young chicks to reduce mortality. World Poultry 18 (11): 24-26.

Lourens, A., and Veldkamp T. (2004). Broeden en opfok kalkoenkuikens (2): de opfok. "Met een temperatuurverloop altijd een lekker plekje". Pluimveehouderij 34 (27):16-18.

Lourens, A., and Meter. T. (2004). Hatchbrood: temperature control at bird level improves broiler performance. Proc. XXII World's Poult. Congress in Istanbul, Turkey p. 206.

Lourens, A., H. van den Brand, R. Meijerhof, and B. Kemp. (2005). Effect of eggshell temperature during incubation on embryo development, hatchability and post-hatch development. Poultry Science 84: 914-920.

Lourens, A. (2010). Broilers in transit: improved welfare in the short broiler chain / Transport van vleeskuikens: welzijnsvoordelen van de Korte Vleeskuikenketen. Rapport 330 Wageningen University Livestock Research. ISSN 1570 - 8616. 34p.

Veldman KT, Wit, B., Pelt, W. , Heederik, D. and Mevius, D.J. (2017). MARAN 2017: Monitoring of antimicrobial resistance and antibiotic usage in animals in the Netherlands in 2016. Combined with NETHMAP-2017: Consumption of antimicrobial agents and antimicrobial resistance among medically important bacteria in the Netherlands..

Mitchell, B. W., and Waltman, W. D. (2003). Reducing airborne pathogens and dust in commercial hatching cabinets with an electrostatic space charge system. Avian diseases, 47, 247-253. 
Nichols, A. A., Leaver, C. W., \& Panes, J. J. (1967). Hatchery hygiene evaluation as measured by microbiological examination of samples of fluff. British poultry science, $8,297-310$.

Nichols, A. A., Leaver, C. W., \& Panes, J. J. (1967). Hatchery hygiene evaluation as measured by microbiological examination of samples of fluff. British Poultry Science, 8, 297-310.

Velkers, F.C.; Jong, I.C. de; Ven, L.J.F. van de; Reep, L. Van de; Stegeman, J.A. (2016). Effects of on-farm hatching on Eimeria infection dynamics. 3rd International Symposium on Parasite Infections in Poultry, Vienna, 2016-07-01/2016-07-02.

Velkers, F.C.; Jong, I.C. de; Ven, L.J.F. van de; Reep, L. Van de; Stegeman, J.A. (2017). Comparison of Eimeria infection dynamics between broiler flocks with a conventional or on-farm hatching system. XXth World Veterinary Poultry Association Congress Edinburgh 2017.

Zurfluh, K., Wang, J., Klumpp, J., Nuesch-Inderbinen, M., Fanning, S., and Stephan, R. (2014). Vertical transmission of highly similar bla CTX-M-1-harboring IncI1 plasmids in Escherichia coli with different MLST types in the poultry production pyramid. Front. Microbiol. 5, 519. 

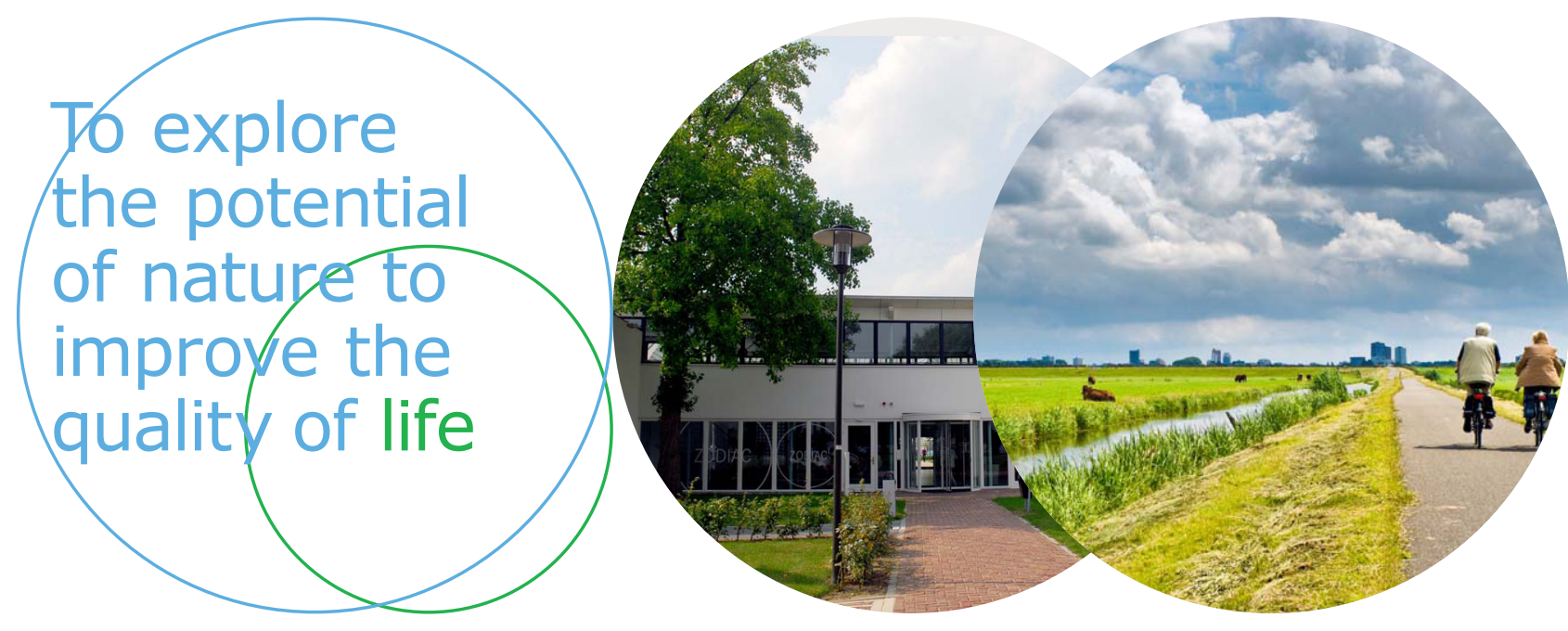

Wageningen Livestock Research P.O. Box 338

$6700 \mathrm{AH}$ Wageningen

The Netherlands

$\mathrm{T}+31(0) 317483953$

E info.livestockresearch@wur.nl www.wur.nl/livestock-research
Wageningen Livestock Research creates science based solutions for a sustainable and profitable livestock sector. Together with our clients, we integrate scientific knowledge and practical experience to develop livestock concepts for future generations.

Wageningen Livestock Research is part of Wageningen University \& Research. Together we work on the mission: 'To explore the potential of nature to improve the quality of life'. A staff of 6,500 and 10,000 students from over 100 countries are working worldwide in the domain of healthy food and living environment for governments and the business community-at-large. The strength of Wageningen University \& Research lies in its ability to join the forces of specialised research institutes and the university. It also lies in the combined efforts of the various fields of natural and social sciences. This union of expertise leads to scientific breakthroughs that can quickly be put into practice and be incorporated into education. This is the Wageningen Approach. 